\title{
THE FUTURE OF FORESTS IN OUR SOCIETY SUMMATION ADDRESS C.I.F. ANNUAL MEETING - OCTOBER, 1964
}

\author{
By D. I. CROSSLEY
}

The apparent purpose of selecting the theme of The Future of Forests in our Society was to focus our attention on two things:

1. The rapidly increasing demand for forest uses other than wood fibre production.

2. The technological revolution that is taking place and creating great changes in the practice of forestry.

Although foresters have, for sometime, been aware of demands for forest use other than wood fibre production they have been inclined to view the various pressures for such uses as local ones, best relieved by a gradual transition and with little sense of urgency. No longer are the forces at work in our society which are likely to influence forest land management the simple economic ones related to the 19th century mercantilism, or the simple building up of strategic supplies of wood for use in national emergencies. Rather, they are those which are increasingly a result of a complex interplay of the political, economic and social actions of the day, and these forces are rushing at us with alarming rapidity. If we as foresters are to play an intelligent part in future forest land management we must be aware of the significant changes in concepts which are taking place in these three spheres. Many of these changes are related to the accelerated urbanization of western man during the last half century, to the increasing rapidity in technological advances, and to the resultant affluent society which has developed. As Professor McLuhan emphasized, every new technology is an invasion that completely reshapes or repatterns our lives.

The significance of forest use by people for recreation and education, and the possible importance of forest or even tree environments to a society in which labor, in the traditional sense, has been, or will shortly be, largely replaced by automation has been but superficially explored, if not barely perceived. If, as Dr. Jewett suggested, our political future is to become one of issue orientation what greater issues can we imagine than those effecting the playground where affluent society will spend much of its leisure time! 
We can take some comfort from the fact that anything that gets people out into the woods, be it hunting, fishing, picnicking, hiking, berry picking all result in a fuller knowledge and understanding of the outdoor environment. Once the public gains some insight into resource management through the increasingly popular outdoor educational programs, we are well on our way to gaining an influential partner in the husbandry of our forest wealth. The average citizen is concerned over the future of any of his country's resources and the natural rhythm of renewable resource husbandry makes sense and can have a strong appeal. Those forest industrialists who are resisting the practising of sustained yield management may soon find themselves out of step with the times and presenting a very tenuous public image. Another appreciation that should not be ignored when considering land use conflicts is the knowledge that similar conflicts are undoubtedly being experienced by our competitors throughout the world. With higher population densities, equal affluence and leisure time, and less forest land, they are the ones who should be most concerned.

We should however not ignore the possibility that "land management" or "resource management" as more embracing terms than "forest management" may become more acceptable, and unless we are prepared to meet the challenge and minimize the frictions by broadening our horizons and our knowledge we as foresters might find ourselves relegated to an ancillary role. Here I would remind you of Dr. Gould's rueful experience of hearing the opinion expressed that "the future of forests is much too important to leave to foresters".

The technological revolution taking place is creating large changes in the practice of forestry from the processes of extraction and transportation to every aspect of utilization and consumer product fabrication. Canada is a nation that must export in order to survive. The necessity of recognizing the increased competition we are going to experience, and of maintaining our share of world markets for wood, must continually focus the attention of forest managers on production costs. While explosive changes are to be expected in the harvesting of wood, unless they are of such a nature as to be applicable only to Canadian terrain and stand conditions, only a temporary competitive advantage will result from their introduction into the woods operation. The problem is not simply one of finding cheaper methods of extracting the wood harvest. In addition we must at least keep abreast of silvicultural knowledge and relate it effectively to stand and forest management. We must minimize the wastage of wood, with our goal the utilization of the whole tree. Stand manipulations and silvicultural controls should be investigated in order that wood may be produced of a predetermined character, although here I feel compelled to express the fear that many of the specifications might not survive the long passage of time that our stands take to reach maturity.

In conclusion I return to the introduction to Dr. Gould's theme address when he referred to the paraphrasing of Clemenceau's epigram about war being too serious a business to leave to generals. I am convinced that since forest wealth plays such a vital role in our national economy the wild land that supports it is too important to be allowed out of our hands. 